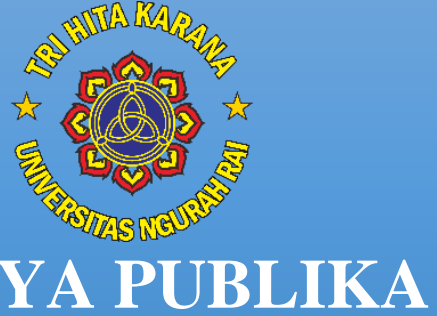

\title{
IMPLEMENTASI PERATURAN DAERAH PROVINSI BALI NOMOR 3 TAHUN 2017 TENTANG LEMBAGA PERKREDITAN DESA (LPD) (Study Penelitian pada LPD Desa Pekraman Sesetan)
}

\author{
Kadek Swadewi Adnjana Putri ${ }^{1,}$ Anak Agung Gede Raka ${ }^{2}$ \\ ${ }^{1}$ Pascasarjana Magister Adminitrasi Publik, Universitas Ngurah Rai; \\ email : Swadewi05@gmail.com \\ ${ }^{2}$ Pascasarjana Magister Adminitrasi Publik, Universitas Ngurah Rai; email : \\ rakaanakagunggde@gmail.com
}

\begin{abstract}
Village Credit Institutions (LPD) is one of the village financial institutions in Bali. Since its establishment, LPD has managed to achieve good performance. Over time, regulations related to LPD have also experienced development. Local Regulation No. 3 of 2017 is the latest regulation on LPD. The purpose of this study was to find out the implementation of Local Regulation Number 3 of 2017. The method used by the writer in this research was descriptive with qualitative methods that aim to make a description, a systematic, factual, accurate description of the facts, the traits and the relationship between the phenomena under investigation which in the end this method is used to find solutions to problems researched. Based on the research results of the implementation of local regulation of Bali Province Number 3 of 2017 there are several things that have not been implemented, including education and training that have been attended by the prajuru and LPD employees of Pakraman Sesetan Village, not yet based on competency. In terms of the organizational structure of the LPD Pekraman Sesetan village not yet referring to the organizational structure which poured in the Bali Governor Regulation No. 44 of 2017.
\end{abstract}

Keywords: Public Policy, Implementation, Village Credit Instirution .

\begin{abstract}
Abstrak
Lembaga Perkreditan Desa (LPD) adalah salah satu lembaga keuangan desa yang ada di Bali. Sejak berdirinya, LPD telah berhasil mencapai kinerja dengan baik. Seiring berjalannya waktu, peraturan terkait LPD juga mengalami perkembangan. Perda No. 3 Tahun 2017 adalah perda terbaru tentang LPD. Tujuan pelaksanaan penelitian ini adalah untuk mengetahui implementasi Peraturan Daerah Provinsi Bali Nomor 3 Tahun 2017. Metode yang digunakan penulis dalam penelitian ini yaitu deskriptif dengan metode kualitatif yang bertujuan membuat deskripsi, gambaran secara sistematis, faktual, akurat, mengenai fakta-fakta, sifat-sifat serta hubungan antara fenomena yang diselidiki yang pada akhirnya metode ini digunakan untuk mencari pemecahan atas masalah yang diteliti. Berdasarkan
\end{abstract}


hasil penelitian pelaksanaan implementasi Peraturan Daerah Provinsi Bali Nomor 3 Tahun 2017 terdapat beberapa hal belum diimplementasikan diantaranya pendidikan dan pelatihan yang telah diikuti oleh prajuru maupun karyawan LPD Desa Pakraman Sesetan belum berbasis kompetensi. Dalam hal struktur organisasi LPD Desa Pakraman Sesetan belum mengacu pada struktur organisasi yang tertuang dalam Peraturan Gubernur Bali Nomor 44 Tahun 2017.

Kata Kunci: Kebijakan Publik, Implementasi, Lembaga Perkreditan Desa

\section{PENDAHULUAN}

\subsection{Latar Belakang Masalah}

Pemerintah Provinsi Bali telah menerbitkan Peraturan Daerah Provinsi Bali Nomor 3 Tahun 2001 sebagaimana telah diubah menjadi Peraturan Daerah Provinsi Bali Nomor 3 Tahun 2003 tentang Perubahan Atas Peraturan Daerah Provinsi Bali Nomor 3 Tahun 2001 tentang Desa Pakraman, yang mengganti istilah desa adat dengan desa pakraman, namun substansi tetap sama.Desa pakraman dalam penyelenggaraan pemerintahan dapat menetapkan aturan-aturan sendiri berupa awig-awig berupa hukum adat. Penyusunan awig-awig desa bersumber dari falsafah Tri Hita Karana, yaitu mengatur keharmonisan hubungan antara manusia dengan Tuhan Yang Maha Esa, manusia dengan sesama manusia, dan manusia dengan alam.

Lembaga Perkreditan Desa merupakan salah satu unsur kelembagaan Desa Pakraman yang menjalankan fungsi keuangan. Berdiri dan berkembangnya Lembaga Perkreditan Desa pada dasarnya untuk pembangunan di tiap-tiap desa adat atau desa pakraman sebagai kekuatan untuk menjaga adat dan budaya Bali yang merupakan suatu strategi dalam meningkatkan sumber pendanaan khususnya terhadap anggota masyarakat setempat. Keberadaan Lembaga Perkreditan Desa menjadi salah satu representasi kearifan lokal dan aset masyarakat Bali yang didirikan oleh mantan Gubernur Bali yaitu Prof. Ida Bagus Mantra pada Tahun 1984. Sampai saat ini, Lembaga Perkreditan Desa yang disingkat LPD, semakin menunjukkan eksistensinya sebagai lembaga keuangan milik desa pakraman atau desa adat yang bertujuan untuk meningkatkan kesejahteraan krama desa pakraman. Sebagai lembaga perekonomian milik desa pakraman, LPD mutlak dikelola dan diarahkan untuk berkontribusi bagi pembangunan desa pakraman, serta bagi 
kesejahteraan krama desa pakraman. LPD memiliki posisi yang unik dan diferensiasi yang kuat jika dibandingkan lembaga keuangan lainnya. LPD lahir dan besar dari desa pakraman atau desa adat dimana lembaga ini bisa berjalan dan berkembang jika para krama adatnya merasa memiliki dan terikat dengan eksistensi LPD.

Pada dasarnya LPD terbentuk berdasarkan ikatan sosio-religius-ekonomis dan membentuk berbagai modal sosial seperti kepercayaan sosial kepada pengurus dan krama adat, rasa kebersaman serta rasa memiliki terhadap LPD dan desa adatnya. Sejumlah unsur modal sosial yang mesti tercermin dalam pengelolaan LPD seperti integritas, kejujuran, solidaritas, rasa memiliki, simpati dan empati, toleransi, kemurahan hati, partisipasi atau menyama braya, keadilan, sikap egaliter, kerjasama dan lain-lain. Pengelolaan LPD tanpa memperhatikan modal sosial tersebut sangat rentan untuk menimbulkan berbagai bentuk kecurangan dan penyalahgunaan wewenang dari para pengelolanya yang dapat mengakibatkan LPD tidak mampu mencapai kesinambungan, dan tidak memberikan manfaat bagi desa pakraman. LPD yang tidak sehat malah akan menjadi beban, benalu dan ibarat kanker yang sedikit demi sedikit menggerogoti keuangan LPD termasuk desa pakraman tempatnya bernaung. Lembaga Perkreditan Desa (LPD) yang tersebar di wilayah Bali merupakan bisnis jasa keuangan yang dikelola oleh Desa Pekraman atau Desa Adat. Badan usaha LPD sepenuhnya dimiliki dan dikelola oleh Desa Adat, merupakan lembaga bisnis yang dikelola dengan tujuan untuk memperoleh laba. Lembaga Perkreditan Desa wajib melaksanakan fungsi perusahaan dalam upaya mengoptimalkan potensi modal sendiri dalam rangka mencapai tujuan mendapatkan laba, sehingga laba tersebut dapat ditanamkan kembali untuk memperkuatstruktur permodalan. Pengelolaan modal yang efektif dan efisien akan menjadi penentu keberhasilan dalam memperkuat cadangan modal baik tujuan memperkuat likuiditas maupun sebagai cadangan yang diperlukan untuk menghadapi risiko kerugian sebagai akibat dari kredit macet tak tertagih serta risiko bisnis lainnya. Lembaga Perkreditan Desa adalah lembaga keuangan yang melaksanakan kegiatan usahanya seperti lembaga perbankan, serta pada intinya bersaing dengan pasar keuangan, sehingga dalam gerak pertumbuhannya tidak 
dapat dipisahkan dengan kondisi pendukung dalam rangka mencapai pertumbuhan usaha, seperti perkembangan struktur permodalan, pertumbuhan aset, serta pengendalian risiko pinjaman.

Sejak awal terbentuknya Lembaga Perkreditan Desa, keberadaan dan aktifitas LPD dilindungi dengan Peraturan Daerah Provinsi Bali tentang LPD, Peraturan Gubernur Bali tentang LPD dan hukum adat di masing - masing desa pakraman. Pembentukan LPD didorong karena mendesak dan menguatnya kebutuhan keuangan desa pakraman dalam menyelenggarakan berbagai fungsi peradaban yang sangat berat dan tidak pernah dipikirkan atau dikerjakan oleh lembaga keuangan umum atau bank manapun juga. Sifat khas LPD juga dibedakan oleh instrumen pengelolanya, yaitu dengan menggunakan instrumen komunikasi dan sosial budaya, seperti awig-awig, pesangkepan, dan terutama tujuannya yaitu keberadaan LPD, lebih dimaksudkan untuk membangun kemampuan keuangan masyarakat desa pakraman, dalam rangka menunjang misi mereka untuk memelihara, menyangga, dan mengembangkan peradaban budaya Bali. Peradaban budaya Bali yang menjadi landasan LPD menjadikan karakteristik LPD juga bersifat sosial, komunal, religius (tidak hanya tanggung jawab secara fisik/sekala namun juga secara non fisik/niskala). Dengan terbangunnya sinergi antara hukum adat di masing - masing desa pakraman dengan Peraturan Daerah Provinsi Bali tentang LPD dan Peraturan Gubernur Bali tentang LPD ternyata mampu menjaga LPD tetap hidup dan berkembang sampai saat ini. Dalam sejarah perkembangan LPD ada beberapa peraturan daerah yang menjadi dasar dalam pembentukan LPD yaitu:

1) Keputusan Kepala Daerah Tingkat I Bali Nomor 972 Tahun 1984.

2) Peraturan Daerah Provinsi Daerah Tingkat I Bali Nomor 2 Tahun 1988 tentang Lembaga Perkreditan Desa.

3) Peraturan Daerah Provinsi Bali Nomor 8 Tahun 2002 tentang Lembaga Perkreditan Desa.

4) Peraturan Daerah Provinsi Bali Nomor 3 Tahun 2007 tentang Perubahan Atas Peraturan Daerah Provinsi Bali Nomor 8 Tahun 2002 tentang Lembaga Perkreditan Desa. 
5) Peraturan Daerah Provinsi Bali Nomor 4 Tahun 2012 tentang Perubahan Kedua Atas Peraturan Daerah Provinsi Bali Nomor 8 Tahun 2002 tentang Lembaga Perkreditan Desa.

Beberapa hal yang diidentifikasi sebagai masalah terkait masih belum terimplementasinya Perda Provinsi Bali No. 3 Tahun2017 tentang LPD sebagai berikut :

1) Belum sepenuhnya Prajuru LPD maupun Panureksa memahami ruang lingkup materi yang diatur dalam Peraturan Daerah Provinsi Bali Nomor 3 Tahun 2017 tentang Lembaga Perkreditan Desa dan Peraturan Gubernur Bali Nomor 44 Tahun 2017 tentang Peraturan Pelaksana Peraturan Daerah Provinsi Bali Nomor 3 Tahun 2017 tentang Lembaga Perkreditan Desa.

2) Belum optimalnya pengelolaan Lembaga Perkreditan Desa, Desa Pekraman Sesetan sesuai dengan Peraturan daerah Nomor 3 Tahun 2017 tentang Lembaga Perkreditan Desa.

Berdasarkan latar belakang yang dikemukakan diatas penelitian tertarik untuk melakukan penelitian dalam bentuk tesis dengan judul "Implementasi Peraturan Daerah Provinsi Bali Nomor 3 Tahun 2017 Tentang Lembaga Perkreditan Desa Di LPD Desa Pakraman Sesetan. Dari berbagai uraian latar belakang permasalahan di atas, maka secara sistematis permasalahan pokok dalam penelitian ini terdiri dari:

1) Bagaimana implementasi Peraturan Daerah Provinsi Bali Nomor 3 Tahun $2017 ?$

2) Apa kendala implementasi Peraturan Daerah Provinsi Bali Nomor 3 Tahun 2017 tentang Lembaga Perkreditan Desa di LPD Desa Pakraman Sesetan?

\section{METODE PENELITIAN}

Metode penelitian yang digunakan dalam penelitian ini bersifat diskriptif kualitatif. Pengumpulan data yang digunakan sebagaimana lazim dalam penelitian kualitatif adalah observasi, wawancara dan dokumentasi. 


\section{HASIL DAN PEMBAHASAN}

\subsection{Sejarah Berdirinya Lembaga Perkreditan Desa (LPD) Desa Pakraman Sesetan}

LPD Desa Pakraman Sesetan berdiri pada tanggal 18 Mei 1989 yang berlokasi di Desa Sesetan, Kecamatan Denpasar Selatan. Dalam upaya mempercepat pertumbuhan dan memperkuat ketahanan ekonomi melalui system ekonomi kerakyatan dapat ditempuh melalui strategi pembangunan yang saling menguatkan yaitu pemberdayaan lembaga adat, budaya dan pemahaman agama, pemahaman system ekonomi kerakyatan serta peningkatan kualitas sumber daya manusia. Guna meningkatkan kemandirian desa pakraman dengan segala aspeknya dipandang perlu mengadakan upaya-upaya untuk memperkuat kedudukan keuangan desa pakraman dengan mendirikan suatu badan usaha simpan pinjam, sekaligus berfungsi sebagai wadah kekayaan desa pakraman dengan nama Lembaga Perkreditan Desa (LPD).

LPD Desa Pakraman Sesetan Denpasar didirikan dengan SK Gubernur No. 317 Tahun 1988. Keberadaan LPD sebagai lembaga keuangan dan sub system dari perbankan nasional mempunyai surat ijin dan daftar hukum yang sah. Demikian juga halnya dengan LPD Desa Pakraman Sesetan memiliki dasar hukum dan perijinan pendirian sebagai berikut :

a. Surat Keputusan Gubernur Kepala I Bali No. 53 Tahun 1987 tentang Pendirian LPD di Provinsi Daerah Tingkat I Bali.

b. Peraturan Daerah Tingkat Bali No. 2 Tahun 1988 tentang Pembentukan Lembaga Perkreditan Desa di setiap Desa Adat di Provinsi I Bali.

c. Surat Keputusan dengan SK Gubernur No. 317 Tahun 1988 tentang Perbentukan Badan Pengurus Lembaga Perkreditan Desa (LPD) Sesetan Denpasar.

Lembaga Perkreditan Desa (LPD) Desa Pakraman Sesetan berlokasi di Jl. Raya Sesetan No. 97 Denpasar. Letak Desa Adat Sesetan cukup strategis berada di wilayah kota Denpasar yang merupakan pusat kegiatan perekonomian di Bali, sehingga pendirian LPD sangat menguntungkan, karena di samping jumlah penduduk yang banyak dan kegatan perekonomian yang cukup tinggi. Permodalan 
yang dimiliki LPD Desa Adat Sesetan terdiri dari modal dasar, modal donasi, cadangan umum dan cadangan tujuan. Modal dasarnya adalah berasal dari Bupati Badung sebesar Rp. 2.000.000,-, modal donasi berasal dari bantuan Bupati dari Gubernur pada awal berdirinya LPD yaitu sebesar Rp. 5.785.500,-, cadangan umum berasal dari sisa hasil usaha disisihkan sebanyak 30\%. Cadangan umum yang dicadangkan oleh LPD yang hingga kini terus meningkat sampai mencapai $30 \%$.

\subsection{Visi dan Misi LPD Desa Pakraman Sesetan}

a. Visi

Menjadi Lembaga Perkreditasi Desa yang Sehat, Kuat dan Produktif yang mampu meningkatkan kesejahteraan dan perekonomian krama desa adat dan kemandirian Desa Adat

b. Misi

1. Meningkatkan keimanan dalam mengurus dan mengelola LPD melalui pemahaman ajaran Agama dan Etika Kerja sehingga terwujud Pengurus Pengelola dan Pengawas LPD yang Profesional berdasarkan pengabdian tulus iklas untuk tetap lestarinya Desa Adat.

2. Meningkatkan perekonomian masyarakat pedesaan dengan mendorong pertumbuhan usaha mikro, kecil dan menengah agar dapat menunjang pembangunan desa adat.

3. Meningkatkan dan mendorong pertumbuhan perekonomian dan pembangunan Desa Pakraman Sesetan serta sebagai sumber pendapatan desa adat.

4. Meningkatkan kinerja LPD melalui system pengelolaan dan pelayanan prima.

5. Meningkatkan daya saing inovasi produk dan peningkatan melalui efisiensi untuk dapat menyediakan jasa pelayanan yang berkualitas dan harga yang kompetetive.

6. Meningkatkan kepedulian LPD terhadap lingkungan desa terutama kepentingan sosial, budaya dan agama. 
7. Mewujudkan pemerataan kesempatan berusaha dan peluang kerja bagi krama desa adat.

\subsection{Implementasi Peraturan Daerah Provinsi Bali Nomor 3 Tahun 2017}

\section{Tentang Lembaga Perkreditan Desa}

a. Sumber Daya Manusia dan Struktur Organisasi di LPD Desa Pakraman Sesetan.

Dalam mengimplementasikan Peraturan Daerah Provinsi Bali Nomor 3 Tahun 2017 tentang Lembaga Perkreditan Desa perlu adanya Sumber Daya Manusia yang mendukung baik dari sisi peryaratan maupun pengetahuan sehingga dengan manajemen yang baik LPD dapat memberikan kontribusi yang lebih bagi desa. Organisasi adalah wadah dari semua peran dalam lini kehidupan dunia institusi, semua perencanaan, pengolongan jabatan dan pembagian pekerjaan yang ada di dalam organisasi, pengorganisasian merupakan salah satu fungsi dasar dalam manajemen untuk mencapai sasaran yang ditetapkan oleh oraganisasi, hal ini berkaitan dengan pengaturan kegiatan, orang dan sumberdaya lainnya. Pengorganisasian membutuhkan struktur yang memperjelas fungsi - fungsi setiap bagian dan sifat hubungan antara bagian - bagian tersebut. Strktur oragnisasi adalah system tugas, alur kerja, hubungan pelaporan dan saluran komunikasi yang dikaitkan secara Bersama dalam pekerjaan individu maupun kelompok.

b. Sistem Administrasi di LPD Desa Pakraman Sesetan.

Sebagai badan usaha keuangan, Lembaga Perkreditan Desa (LPD) harus melaksanakan sistem administrasi yang mampu menghasilkan laporan keuangan secara transparan dan akuntable. Transparan berarti memberikan informasi keuangan yang terbuka dan jujur kepada masyarakat berdasarkan pertimbangan bahwa masyarakat memiliki hak untuk mengetahui secara terbuka dan menyeluruh atas pertanggungjawaban dalam pengelolaan sumber daya yang dipercayakan dan ketaatan pada peraturan perundang - undangan. Akuntable adalah dapat dipertanggungjawabkan sesuai dengan peraturan perundang - undangan yang berlaku, serta tidak bertentangan dengan kedua hal tersebut, di mana 
pertanggungjawaban ini menyangkut sumber / infutnya, proses yang dilakukan dan juga hasil / output yang didapat.

Penilaian Kesehatan LPD Desa Pakraman Sesetan. Penilaian kesehatan LPD dilaksanakan secara rutin tiga bulanan maupun secara insidentil atau sesuai dengan kebutuhan. Hasil penilaian kesehatan LPD disampaikan kepada pihak yang terkait untuk mendapatkan pembinaan guna memperbaiki kinerja LPD.

\subsection{Kendala Implementasi Peraturan Daerah Provinsi Bali Nomor 3 Tahun 2017 Tentang Lembaga Perkreditan Desa}

Kendala yang dihadapi LPD Desa Pakraman Sesetan saat ini adalah penerapan sanksi kepada peminjam karena peminjam merupakan krama Desa Adat. Penyitaan angunan tidak dapat dilakukan secara serta merta seperti halnya dilakukan oleh pihak Bank karena peminjam merupakan krama adat.

\subsection{Solusi Terhadap Kredit Maset Atau Kredit Bermasalah}

Permasalahan yang ada LPD Desa Pakraman Sesetan adalah pemberian sanksi terhadap kredit yang bermasalah atau kredit macet. LPD Desa Pakraman Sesetan masih mengunakan system kekeluargaan dan kesepakatan. Solusi terhadap kredit macet atau kredit bermasalah akan diadakan pararem pada masing - masing desa terkait acuan untuk sanksi adatnya.

\section{PENUTUP}

\subsection{Simpulan}

Berdasarkan seluruh pembahasan dari hasil penelitian yang telah dilakukan sebagai pendukung pembahasan dalam Implementasi Peraturan Daerah Nomor 3 Tahun 2017 tentang Lembaga Perkreditan Desa dapat ditarik beberapa kesimpulan sebagai berikut :

1) Peraturan Daerah Nomor 3 Tahun 2017 tentang Lembaga Pekreditan Desa belum sepenuhnya dipahami oleh prajuru maupun karyawan LPD Desa Pakraman Sesetan karena kurangnya sosialisasi Peraturan Daerah Provinsi Bali Nomor 3 Tahun 2017 tentang Lembaga Perkreditan Desa serta Peraturan 
Gubernur Bali Nomor 44 tahun 2017 tentang Peraturan Pelaksanaan Peraturan Daerah Provinsi Bali Nomor 3 Tahun 2017 tentang Lembaga Perkreditan. Desa dalam pelaksanaan Implementasi Peraturan Daerah Nomor 3 Tahun 2017 terdapat beberapa hal belum diimplementasikan diantaranya :

a) Pendidikan dan pelatihan yang telah diikuti oleh prajuru maupun karyawan LPD Desa Pakraman Sesetan belum berbasis kompetensi.

b) Struktur organisasi yang ada di LPD Desa Pakraman Sesetan Pamucuk atau Kepala LPD langsung berada dibawah Desa Pakraman sedangkan struktur organisasi dalam Peraturan Gubernur Bali Nomor 44 tahun 2017 yang langsung dibawah Desa Pakraman adalah Panureksa atau Badan Pengawas. Begitu juga Bagian Pembukuan, Bagian Umum, Bagian Kredit dan Bagian Dana ada dibawah Penyarikan (Tata Usaha) dan Petengen (Bendahara) sedangkan dalam struktur organisasi dalam Peraturan Gubernur Bali Nomor 44 tahun 2017 Kepala Bagian Umum, Kepala Bagian Dana dan Kepala Bagian Kredit dibawah Pemucuk atau Kepala LPD. Begitu juga dalam bidang kredit pada Peraturan Gubernur Bali Nomor 44 tahun 2017 dalam struktur organisasi dicantumkan adanya analisis kredit dan pembinaan kredit serta kolektor sedangkan pada struktur organisasi LPD Desa Pakramana Sesetan hanya mencantumkan penagihan kredit

2) Permasalahan yang ada LPD Desa Pakraman Sesetan adalah pemberian sanksi terhadap kredit yang bermasalah atau kredit macet. Jumlah kredit macet pada LPD Desa Pakraman Sesetan adalah sebesar Rp 302.397.900,00. LPD Desa Pakraman Sesetan tidak bisa seperti Bank langsung mengenakan sanksi bagi nasabah. LPD Desa Pakraman Sesetan masih mengunakan system kekeluargaan dan kesepakatan. Solusi terhadap kredit macet atau kredit bermasalah akan diadakan pararem pada masing - masing desa terkait acuan untuk sanksi adatnya.

\subsection{Saran}

1) Lembaga Pembedayaan LPD agar secara intensif melakukan sosialisasi serta mengembangkan program pelatihan dan menyelenggarakan pelatihan yang berbasis kompetensi bagi prajuru, karyawan dan panureksa LPD. LPD Desa 
Pakraman Sesetan agar segera menyesuaikan Struktur organisasi sesuai dengan Peraturan Gubernur Bali Nomor 44 tahun 2017.

2) Upaya mengatasi kredit bermasalah disamping penerapan pararem hendaknya karyawan bagian kredit secara terus menerus mengadakan pendekatan secara persuasif kepada nasabah yang kreditnya bermasalah.

\section{DAFTAR PUSTAKA}

\section{Sumber Buku}

Arikunto. 2002. Prosedur Penelitian; Suatu Pendekatan Praktek. Jakarta. Reneka Cipta.

Afan Gaffar. 2009. Otonomi Daerah dalam Negara Kesatuan. Yogyakarta; Pustaka Pelajar

Dunn, William N. (2001). Muhadjir Darwin (editor). Analisis Kebijaksanaan Publik. Yogyakarta: Hanindita Graha Widya.

Dwijowijoto, Riant Nugroho. 2003. Kebijakan Publik, Formulasi, Implementasi, Dan Evaluasi. Jakarta: PT Elex Media Komputindo Kelompok Gramedia.

Easton, David. 1965. A System Analysis of Political Life. New york. Willey.

Howlett, Michael and M. Ramesh. 1995. Studying Public Policy: Policy Cycles and Policy Subsystems. Oxford University Press, Oxford.

Lasweel, Harold, dan Abraham Kaplan. 1970. Power And Society, New Heaven. Yale University Press.

Moleong, Lexy J. 2000. Metodologi Penelitian Kualitatif. Bandung. Remaja Rosda Karya.

Nasution, S. 1991. Metode Research Penelitian Ilmiah. Bandung. Jermais.

Nugroho, Riant. 2011. Public Policy. Jakarta. PT Elex Media Komputindo Kelompok Gramedia.

Rakhmat. 2018. Administrasi dan Akuntabilitas Publik. Yogyakarta. Andi.

Subarsono, AG. 2009. Analisis Kebijakan Publik, Konsep, Teori dan Aplikasi. Yogyakarta: Pustaka Pelajar. 


\section{Sumber Jurnal / Artikel /Tesis}

Yoni I Gusti Ayu, 2006 dengan judul “Peran Serta Lembaga Perkreditan Desa (LPD) Desa Pakraman Ubung, Denpasar dalam Menunjang Kewirausahaan Nasabahnya : Perspektif Kajian Budaya" Universitas Udayana.

Cendikiawan (2006) dalam penelitiannya yang berjudul “ Eksistensi Lembaga Perkreditan Desa (LPD) Desa Pakraman Mas Ubud Gianyar, Studi Potensi dan Kendala,"

Windia (2007) menulis jurnal berjudul “ Analisis Bisnis yang Berlandaskan Tri Hita Karana".

Sumarhaeni I Gusti Ayu Sri, 2008 berjudul "Kewenangan Pemerintah Provinsi Bali Dalam Pengaturan Tentang Lembaga Perkreditan Desa" Universitas Udayana

Jayanthi Devi Ni Made, 2016 berjudul “ Status Dan Kedudukan Hukum Lembaga Perkreditan Desa (LPD) Terkait Pengikatan Jaminan Dengan Berlakunya Undang-Undang Nomor 1 Tahun 2013 Tentang Lembaga Keuangan Mikro" Universitas Udayana

Arka (2016) berjudul "Eksistensi Lembaga Perkreditan Desa Dalam Pembangunan Desa Pekraman Sebagai Desa Wisata Di Bali” GaneC Swara Vol 10

Adnyani Sonya Ketut, 2017 berjudul "Praktik Tata Kelola Dalam Perspektif Nilai Budaya Lokal Pada Lembaga Perkreditan Desa (LPD)" Universitas Gajah Mada

Kristiadi Putra I Made 2017 berjudul "Modal sosial dalam pemberdayaan Desa Pakraman :: Studi kasus pengelolaan LPD Desa Pakraman Batuaji Kawan, Kabupaten Tabanan Propinsi Bali “ Universitas Gajah Mada

Sadiartha Anak Agung Ngurah Gede (2017) berjudul "Lembaga Perkreditan Desa Sebagai Penopang Ke-Ajegan Budaya Ekonomi Masyarakat Bali “ Universitas Hindu Indonesia

Bagiada I Made (2017) berjudul "Analisis Kesehatan Lembaga Perkreditan Desa (LPD) Studi Kasus Pada Lpd Desa Adat Kedonganan Kuta - Badung Tahun 2013 - 2015" Politeknik Sekayu Vol VI 